\title{
Chemical composition, digestibility and energy content of leguminous grains and straws grown in a Mediterranean region
}

\author{
M. HADIIPANAYIOTOU, S. ECONOMIDES and A. KOUMAS \\ Agricultural Research Institute, Nicosia, Cyprus
}

\begin{abstract}
Summary
Apparent digestibility cocfficients of five leguminous grains (chick peas, field beans and Cyprus, bitter and common vetch) and their straws were determined in two separate experiments with Chios wether sheep.

The crude protein (CP) and crude fibre (CFi) content ( $\mathrm{g} / \mathrm{kg} \mathrm{DM}$ ) of Cyprus vetch, bitter vetch, chick peas, field beans and common vetch were for grains 313,$79 ; 261,35$; 202,$47 ; 260,102 ; 290,52$; and for straws 81,$349 ; 72,308 ; 41,410 ; 98,272 ; 70,351$, respectively. Organic matter (OM), gross energy (GE) and $C P$ digestion coefficients (p. 100) and Digestible energy (DE) content $(\mathrm{MJ} / \mathrm{kg} \mathrm{DM})$ were for grains $86,81,85,14.6 ; 89$, $85,86,15.1 ; 84,79,79,15.0 ; 88,83,82,15.0 ; 91,84,86,14.6$ and $53,53,55,9.1$; $60,57,44,9.3 ; 51,49,20,8.3 ; 60,50,43,8.9 ; 57,56,35,9.4$ for straws, respectively.

It is concluded that the leguminous grains used are good sources of protein, of high digestibility and of high energy content and that their straws are of higher nutritive value than cereal straws. The relatively lower digestion coefficients obtained with chick peas grain, than with the other grains used, might be associated with its lower CP content, whereas the lower values obtained from chick peas straw might be associated with their low $\mathrm{CP}$ and high CFi contents.
\end{abstract} sheep.

Key words : digestibility, chemical composition, leguminous grains, leguminous straws,

\section{Introduction}

In Mediterranean countries, especially those with intensive livestock production systems there is a wide gap between demand and production of feedstuffs rich in protein (FAO, 1981). Soyabean meal is the most extensively used protein supplement ; however, under the low rainfall conditions prevailing in the region and high requirements for water, soyabean cannot compete with cash crops and/or other crops with lower water demands. On the other hand, there are many species of legumes which are potentially adapted to the dryland agricultural regions of Mediterranean countries. In addition to their value as a feedstuff, legumes are also important in rotation systems because of their ability to fix atmospheric nitrogen and so increasing the overall fertility of the soil. 
The agronomic aspects of some rainfed leguminous crops for forage production have been studied by HaDjICHRISTODOUlou (1976). Furthermore, studies are in progress (I. Papastrlianou, unpublished) comparing the production of grain and straw from legume and cereal crops. There has been very little work on the nutritional value of leguminous grains or straws grown under semi-arid conditions.

This paper reports a study of the digestibility of five leguminous grains and their straws fed to Chios wether sheep.

\section{Material and methods}

Apparent digestibility coefficients of five leguminous grains and their straws were determined in two scparate experiments.

\section{Experiment 1}

Twentythree year old Chios wether sheep of approximately $65 \mathrm{~kg}$ live weight were used. The animals were housed in metabolism crates designed for the separate collection of urine and faeces. All animals were given a basic ration for a period of 21 days. The first 14 days served as adaptation period and the other seven as faecal collection period. The basic ration consisted of $540 \mathrm{~g}$ concentrate mixture (18.8 MJ GE $/ \mathrm{kg} \mathrm{DM}$ ) and $170 \mathrm{~g}$ chopped barley straw (18.7 MJ GE/kg DM) per animal per day and its protein content was $152 \mathrm{~g} / \mathrm{kg}$ on dry matter (DM) basis. The concentrate mixture composed of $(\mathrm{g} / \mathrm{kg}) 460$ barley grain, 308 sorghum grain, 164 soyabean meal, 50 wheat bran, 5 dicalcium phosphate, 10 limestone and 3 sodium chloride. A mineral-vitamin mixture was added to supply 6,000 I.U. vitamin A, 1,000 I.U. vitamin $D_{3}, 8.5$ I.U. vitamin E, $25 \mathrm{mg} \mathrm{Mn}, 1.75 \mathrm{mg} \mathrm{I}, 45 \mathrm{mg} \mathrm{Zn}$, $30 \mathrm{mg} \mathrm{Fe}, 2 \mathrm{mg} \mathrm{Co}$ and $60 \mathrm{mg} \mathrm{Mg}$ per $\mathrm{kg}$ of concentrate mixture. When the digestibility of the basic ration was determined the animals were randomly divided into five groups of four animals each, and each group was allocated to one of the grains on test (Table 1). Each grain was added $(300 \mathrm{~g} /$ head/day) to the basic ration for 17 days. The first 10 days served as adaptation period and the last seven days as faecal collection period. The difference method (MCDONALD, EDWARDS \& GREENHALGH, 1973) was used to calculate digestion coefficient of the feedstuffs on test. The higher intake (I) and faecal (F) output associated with the added ingredient on test were fitted in the equation $\frac{I-F}{I} \times 100=$ Digestibility $(\%)$ for measuring. its digestibility. Leguminous grains on test, were grown locally under rainfed conditions. Individual feed intake was recorded daily. The animals had free access to water. During the collection period twenty percent of the daily output of faeces was stored at $-20^{\circ} \mathrm{C}$ for providing a bulk sample at the end of the trial. Representative samples of faeces were homogenized with water before being analyzed for total nitrogen (Macro-Kjeldahl procedure). Other chemical analyses on feeds and faeces were made on dried $\left(55^{\circ} \mathrm{C}\right)$ samples ground to pass a $1 \mathrm{~mm}$ sieve by the methods of the Association of Official Agricultural Chemists (1975). Using a Ballistic Bomb Calorimeter the gross energy (GE) of feeds and faeces was determined. 


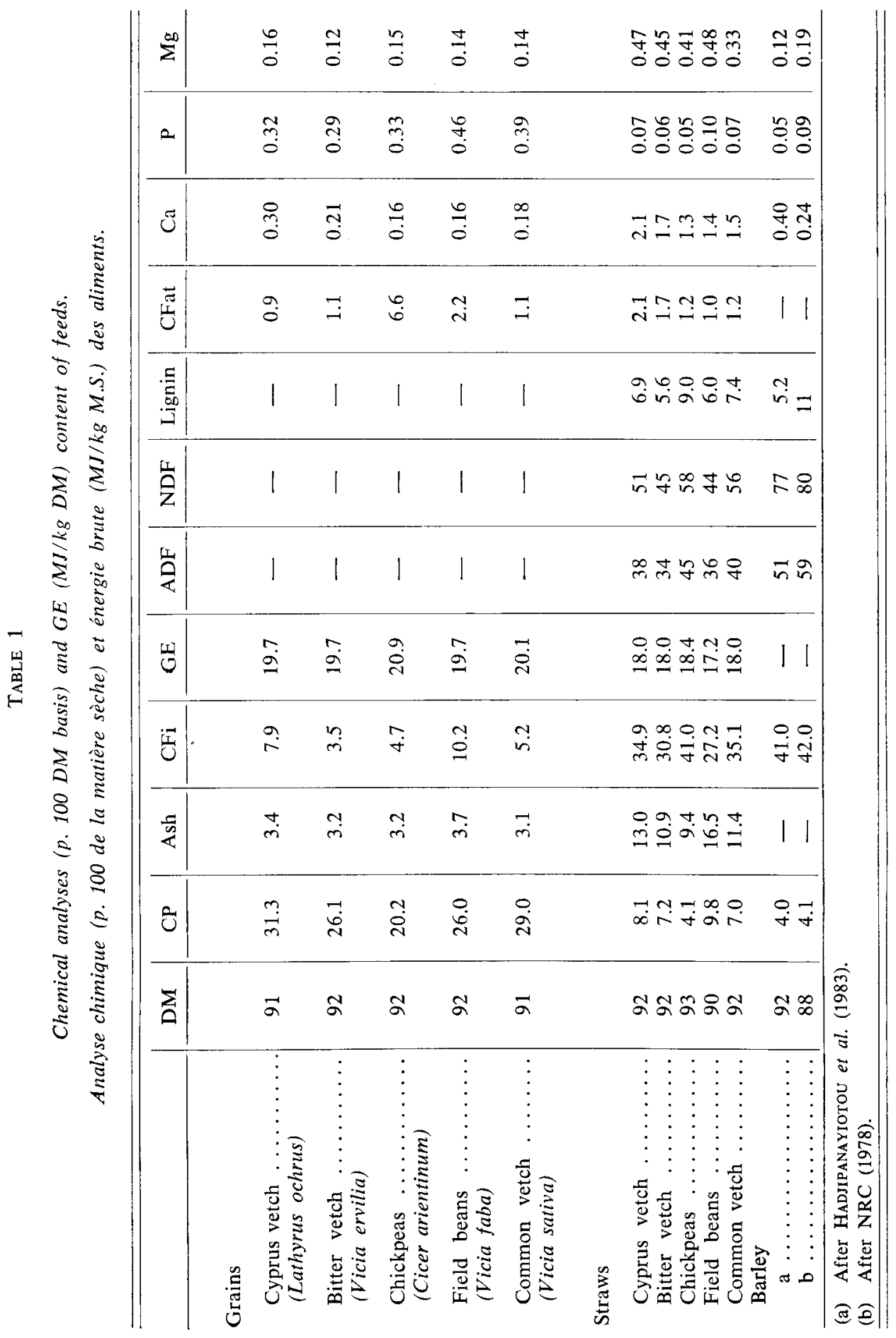


The experimental design was completely randomized and statistical analyses were performed accordingly (STEEL \& TORRIE, 1960). Differences among treatment means were tested using the Duncan's multiple range test.

\section{Experiment 2}

Twenty Chios wethers of approximately $48 \mathrm{~kg}$ body weight and 18 months old were used. Housing and management were identical to those employed in experiment 1 . The daily basic ration consisted of $400 \mathrm{~g}$ concentrate (similar to that used in experiment 1) and $200 \mathrm{~g}$ chopped barley straw. The straws on test (Table 1) were added to the basic ration $(500 \mathrm{~g} /$ head/day). All straws were collected from the same area. Field beans straw contained $70 \mathrm{~g} / \mathrm{kg}$ cracked seeds. Acid (ADF) and neutral (NDF) detergent fibre and lignin were determined by the method of Gol:RING \& VAN Soest (1970). Other analyses were similar to those made in experiment 1. The experimental design and statistical analysis were also similar.

\section{Results and discussion}

The chemical composition of the leguminous grain tested is shown in Table 1. Crude protein (CP) content ranged from 202 to $313 \mathrm{~g} / \mathrm{kg}$ DM ; the level of crude fibre (CFi) were generally below $105 \mathrm{~g} / \mathrm{kg}$ DM and only the crude fat (CFat) content of chickpeas exceeded $60 \mathrm{~g} / \mathrm{kg}$ DM. The highest $\mathrm{CP}$ content was found in Cyprus and common vetch which had almost similar CP content.

Chickpeas had the lowest CP content whereas, field beans and bitter vetch were in between. The CFi content of field bean grains was the highest; differences among the other leguminous grains were not significant. Despite the fact that legume grains were bought from the local market, and it is more likely that they were grown under different environmental conditions (soil fertility, rainfall) their CP content was similar to those grown under rainfed conditions in the same field (I. Papastrlianou, unpublished). Indeed, nitrogen content of nodulated common, Cyprus or bitter vetch grains is not affected by nitrogen fertilizer. Cyprus vetch had slightly higher $\mathrm{Ca}$ content than the other local grains. In accordance with Church (1980) grains were moderate sources of $\mathrm{P}$ and $\mathrm{Mg}$ but contained very little $\mathrm{Ca}$.

Chickpeas straw had the lowest CP (40 g/ $\mathrm{kg}$ DM) and the highest CFi $(400 \mathrm{~g} / \mathrm{kg}$ DM) content (Table 1). Chickpeas straw had also higher ADF, NDF and lignin values than the other straws. With the exception of chickpeas straw other straws had lower CFi and higher CP contents than reported values for barley straw (Table 1). Furthermore, barley straw had higher ADF and NDF values than leguminous straws (Table 1).

Digestion coefficients of the basic diets used in the two experiments are shown in Table 2. There were differences between experiments. The lower values obtained in experiment 2 compared to experiment 1 were possibly due to the higher proportion (33.3 vs 23.9) of straw in the finished diet and the higher level of intake (29 vs $26 \mathrm{~g} / \mathrm{kg} \mathrm{W}^{(0.75)}$. 
TABLE 2

Digestibility coefficients of the basic diets.

Coefficients de digestibilité des rations de base.

\begin{tabular}{|c|c|c|c|c|}
\hline \multirow{3}{*}{ Digestibility (\%) } & \multicolumn{4}{|c|}{ Experiment } \\
\hline & \multicolumn{2}{|c|}{1} & \multicolumn{2}{|c|}{2} \\
\hline & Mean & $\mathrm{SD}$ & Mean & SD \\
\hline Dry matter $\ldots \ldots \ldots \ldots \ldots \ldots$ & 76.3 & 1.40 & 70.4 & 2.47 \\
\hline Organic matter $\ldots \ldots \ldots \ldots \ldots$ & 78.7 & 1.48 & 71.3 & 2.16 \\
\hline Crude protein $\ldots \ldots \ldots \ldots \ldots \ldots$ & 79.3 & 2.08 & 72.7 & 4.93 \\
\hline Gross energy $\ldots \ldots \ldots \ldots \ldots \ldots$ & 76.7 & 1.93 & 68.6 & 2.89 \\
\hline
\end{tabular}

TABLE 3

Feed intake, digestibility coefficients of whole diets, grains on test and their DE content, Consommation, coefficients de digestibilité des rations totales et des graines testées et leur teneur en énergie digestible.

\begin{tabular}{|c|c|c|c|c|c|c|}
\hline & $\begin{array}{l}\text { Cyprus } \\
\text { vetch }\end{array}$ & $\begin{array}{l}\text { Bitter } \\
\text { vetch }\end{array}$ & $\begin{array}{l}\text { Chick } \\
\text { peas }\end{array}$ & $\begin{array}{l}\text { Field } \\
\text { beans }\end{array}$ & $\begin{array}{l}\text { Common } \\
\text { vetch }\end{array}$ & $\begin{array}{l}\text { s.e. of } \\
\text { treatment } \\
\text { means }\end{array}$ \\
\hline \multicolumn{7}{|l|}{ Feed intake (g DM/day) } \\
\hline Concentrate $\ldots \ldots \ldots$. & 488 & 488 & 488 & 488 & 488 & - \\
\hline Barley straw $\ldots \ldots \ldots$ & 157 & 157 & 157 & 157 & 157 & - \\
\hline Ingredient on test $\ldots \ldots$ & 273 & 276 & 276 & 276 & 272 & 一 \\
\hline \multicolumn{7}{|l|}{$\begin{array}{l}\text { Digestibility }(\%) \\
\text { of the whole dict }\end{array}$} \\
\hline Dry matter $\ldots \ldots \ldots \ldots$ & 79 & 80 & 77 & 80 & 79 & 0.9 \\
\hline Organic matter $\ldots \ldots \ldots$ & 82 & 82 & 80 & 82 & 82 & 0.9 \\
\hline Gross energy $\ldots \ldots \ldots$ & 79 & 79 & 77 & 78 & 78 & 1.0 \\
\hline Crude protein ... & 83 & 82 & 78 & 81 & 81 & 1.1 \\
\hline $\mathrm{DE}(\mathrm{MJ} / \mathrm{kg} \mathrm{DM}) \ldots \ldots \ldots$ & 14.6 & 14.7 & 14.5 & 14.6 & 14.4 & 0.21 \\
\hline \multicolumn{7}{|l|}{$\begin{array}{l}\text { Digestibility (\%) } \\
\text { of the ingredient on test }\end{array}$} \\
\hline Dry matter ...... & 85 & 88 & 82 & 87 & 89 & 2.6 \\
\hline Organic matter .... & 86 & 89 & 84 & 88 & 91 & 2.6 \\
\hline Gross energy $\ldots \ldots$ & 81 & 85 & 79 & 83 & 84 & 3.1 \\
\hline Crude protein ..... & 85 & 86 & 79 & 82 & 86 & 2.1 \\
\hline $\mathrm{DE}(\mathrm{MJ} / \mathrm{kg} \mathrm{DM}) \ldots \ldots$ & 14.6 & 15.1 & 15.0 & 15.0 & 14.6 & 0.61 \\
\hline
\end{tabular}


There were no differences in feed intake of the basic ration (concentrate + barley straw) or the leguminous grains on test (Table 3). The digestion coefficients for DM, OM, GE and CP and the Digestible energy (DE) content of the whole diet and of the grains on test are also shown in Table 3. Although chickpeas grains tended to have lower digestion coefficients than the other grains, differences were not significant. The trend towards lower digestion coefficients however, might be ascribed to its lower CP content. Organic matter and CP digestion coefficients $(\%)$ for ficld beans $(78,79)$ or vetch grains $(82,82)$ reported by MAFF $(1975)$ were close to those found in the present studies. The Arab \& Middle East tables of Feed composition (1979) give $\mathrm{CP}, \mathrm{CFi}(\%)$ and DE (MJ/kg DM) contents of $28.6,11.0,14.9 ; 28,6.8,15.2$ for field beans and common vetch grains, respectively, which are in good agreement with our findings. Furthermore, $\mathrm{ME}(\mathrm{DE} \times 0.82)$ content of all grains was close to that for extracted soyabean meal given by MAFF (1975) and NRC (1978).

\section{TABLE 4}

Feed intake, digestibility coefficients of whole diets, straws on test and their DE content.

Consommation, coefficients de digestibilité des rations totales, des pailles testées et leur teneur en énergie digestible.

\begin{tabular}{|c|c|c|c|c|c|c|}
\hline & $\begin{array}{l}\text { Cyprus } \\
\text { vetch }\end{array}$ & $\begin{array}{l}\text { Bitter } \\
\text { vetch }\end{array}$ & $\begin{array}{l}\text { Chick } \\
\text { peas }\end{array}$ & $\begin{array}{l}\text { Field } \\
\text { beans }\end{array}$ & $\begin{array}{c}\text { Common } \\
\text { vetch }\end{array}$ & $\begin{array}{l}\text { s.e. of } \\
\text { treatment } \\
\text { means }\end{array}$ \\
\hline \multicolumn{7}{|l|}{ Feed intake (g DM/day) } \\
\hline Concentrate. & 363 & 363 & 363 & 361 & 362 & - \\
\hline Barley straw .... & 186 & 186 & 186 & 186 & 186 & - \\
\hline Ingredient on test $\ldots .$. & 458 & 458 & 458 & 458 & 458 & - \\
\hline \multicolumn{7}{|l|}{$\begin{array}{l}\text { Digestibility }(\%) \\
\text { of the whole diet }\end{array}$} \\
\hline Dry matter $\ldots \ldots \ldots \ldots$ & $61^{\mathrm{b}}$ & $65^{: 1}$ & $60^{11}$ & $64^{\prime \prime}$ & $63^{\mathrm{ab}}$ & 1.0 \\
\hline Organic matter $\ldots \ldots \ldots$ & $63^{\prime \prime}$ & $66^{: 4}$ & $62^{1}$ & $66^{: 1}$ & $65^{\mathrm{ab}}$ & 1.1 \\
\hline Gross energy $\ldots \ldots \ldots$ & $61^{1 \mu}$ & $64: 111$ & $59 \mathrm{c}$ & $64^{\mathfrak{u}}$ & $63^{\mathrm{ab}}$ & 0.8 \\
\hline Crude protein .... & $66^{a 11}$ & $66^{416}$ & $60^{c}$ & $62^{\text {be }}$ & $64 a b c$ & 1.2 \\
\hline $\mathrm{DE}(\mathrm{MJ} / \mathrm{kg} \mathrm{DM}) \ldots \ldots$ & $10.97: 11$, & $11.5^{:}$ & $10.7^{b}$ & $11.3^{\mathfrak{a}}$ & $11.3^{\mathrm{a}}$ & 0.15 \\
\hline \multicolumn{7}{|l|}{$\begin{array}{l}\text { Digestibility }(\%) \\
\text { of the ingredient on test }\end{array}$} \\
\hline Dry matter ......... & 52 & 58 & 49 & 56 & 56 & 3.2 \\
\hline Organic matter ....... & 53 & 60 & 51 & 60 & 57 & 2.5 \\
\hline Gross energy $\ldots \ldots \ldots$ & 53 & 57 & 49 & 55 & 56 & 2.2 \\
\hline Crude protein $\ldots . . .$. & 55 & 44 & 20 & 43 & 35 & 7.9 \\
\hline $\mathrm{DE}(\mathrm{MJ} / \mathrm{kg} \mathrm{DM}) \ldots \ldots \ldots$ & 9.1 & 9.3 & 8.3 & 8.9 & 9.4 & 0.56 \\
\hline
\end{tabular}


Intake of individual ingredients, digestion coefficients of whole diets (basic + leguminous straw), straws on test and their DE content are shown in Table 4 . There were no feed residues in the present study. Mixed diets (basic + straw on test) containing bitter vetch, field beans or common vetch had higher apparent digestion coefficients of DM and OM. Differences however, were significant only between the mixed diet containing bitter vetch or field beans and those containing Cyprus vetch or chickpeas straw. The mixed diet containing chickpeas straw had the lowest GE and $C P$ digestibility; differences reached significance $(P<0.05)$ only against bitter vetch, field beans and common vetch for GE and Cyprus vetch and bitter vetch for CP. Furthermore, DE content of the mixed diet containing chick peas straw was significantly lower $(P<0.05)$ than that of mixed diets containing bitter vetch, field beans or common vetch. Although differences in digestion coefficients and DE content among the added ingredients did not reach significance, chickpeas straw tended to have lower digestion coefficients than the other straws. This can be ascribed to its lower CP and higher CFi and lignin contents than the other straws. Indeed, the CFi and $\mathrm{CP}$ content of chickpeas straw was similar to previously reported values for barley straw (Table 1). The three vetch straws had significantly higher digestion coefficients for $\mathrm{CP}$ and $\mathrm{OM}$ than previously reported values for barley straw (MAAF, 1975 : winter barley 22, 42 ; spring barley 24, 51 ; HaDJIPANAYOTOU et al., $1983: 0,46)$. Furthermore, CP digestibility of field beans and the three vetch straws on test in the present study were similar to those reported by MAFF (1975) for peas straw (48 p. 100) and vetch straw (46 p. 100).

Although leguminous grains are good sources of digestible $\mathrm{CP}$, and ruminants might be less sensitive than monogastric to anti-nutritional factors which are present in leguminous grains, further research is required before recommending inclusion of large quantities of these feedstuffs in ruminant diets. Finally, these studies showed that with the exception of chickpeas the other leguminous straws were of higher nutritive value than cereal straws.

\title{
Acknowledgements
}

The authors thank J.P. Hogan for reviewing the manuscript. I. Papastylianou for supplying the straws, A. Photiou, N. Parouti, M. Karavia, M. Theodoridou and the staff of the Chemistry Laboratory for skilled technical assistance. This study was supported in part by FAO/IAEA, Vienna.

\author{
Résumé \\ Composition chimique, digestibilité et teneur en énergie \\ des graines et pailles de légumineuses d'origine méditerranéenne
}

Les coefficients de digestibilité apparents de cinq graines de légumineuses (pois chiche, féverole, vesce Cyprienne, vesce amère et vesce commune) et de leurs pailles sont déterminés au cours de deux expériences avec des moutons de Chio.

Les teneurs en protéines brutes (P.B.) et en cellulose brute (C.B.) sont (en grammes par $\mathrm{kg}$ de matière sèche) de 313,$79 ; 261,35 ; 202,47 ; 260,102 ; 290,52$; et de 81,349 ; 72,$308 ; 49,410 ; 98,272 ; 70,351$ respectivement pour les graines et la paille de la vesce Cyprienne, vesce amère, poids chiche, féverole et vesce commune. 
Les coefficients de digestibilité (en p. 100) de la matière organique (M.O.) de l'énergie brute (E.B.), des protéines brutes (P.B.) et les teneurs en énergie digestible (E.D.) en (MJ $/ \mathrm{kg}$ M.S.) sont de $86,81,85,14.6 ; 89,85,85,15.1 ; 84,79,79,15.0 ; 88,83,82,15.0$; $91,84,86,14.6$ pour les graines et de $53,53,55,9.1 ; 60,57,44,9.3 ; 51,49,20,8.3$; $60,50,43,7.6 ; 57,56,35,19.4$ pour les pailles.

On peut en conclure que les graines de légumineuses sont une bonne source de protéines, qu'elles sont très digestibles et riches en énergie. Leurs pailles ont une valeur nutritive supérieure à celles des céréales.

Les coefficients de digestibilité relativement faibles des graines de pois chiche peuvent être dus à une tencur moins élevée en protéines brutes. Les valeurs moindres qu'on obtient pour les pailles de pois chiche et de féverole, peuvent être associées à leur teneur réduite en protéines brutes et leur richesse en cellulose brute. mouton.

Mots clés : digestibilité, composition chimique, graines et pailles de légumineuses,

Regu en avril 1984.

accepté en décembre 1984.

\section{References}

Arab and middle east tables of feed composition, 1979. ACSAD-AS-P1-1979 and Intern. Feedstuffs Inst., Utah Agric. Experiment Station, Logan, Utah. Research Report, 30, p. 554.

A.O.A.C., 1974 (Association of Official Analytical Chemists). Official Methods of Analysis, p. 1094 (Horwitz W., Ed.). Washington, D.C.

Church D.C., 1980. Digestive physiology and nutrition of ruminants. Vol. 3. Practical Nutrition. 2nd ed., p. 416 (Church D.C., Ed.), O \& B Books Inc., NJ.

F.A.O., 1981 (Food and Agriculture Organization). F.A.O. trade year-book. Vol. 35, p. 368. Food and Agriculture Organization of the United Nations.

Goering H.K., VAn Soest P.J., 1970. Forage fibre analyses, apparatus, reagents, procedures and some applications. Agricultural Research Service, U.S. Department of Agriculture. Agricultural Handbook No. 379.

HADJichristodoulou A., 1976. Effect of harvesting stage on cereal and legume forage production in low rainfall regions. J. Agric. Sci. Camb., 86, 155-161.

Hadipanayiotou M., Economides S., Hadjidemetriou D., 1983. The chemical composition of feedstuffs commonly used in ruminant diets. Miscellaneous Reports, 9, Agricultural Res. Institute, Nicosia, Cyprus.

McDonald P., Edwards R.A., Greenhalgh J.F.D., 1973. Animal Nutrition. 2nd Ed., p. 479, Logman, London and New York.

M.A.F.F., 1975 (Ministry of Agriculture, Fisheries and Food). Technical Bulletin 33. Energy Allowances and Feeding Systems for Ruminants, p. 79. H.M.S.O., London.

N.R.C., 1978 (National Rescarch Council). Nutrient Requirements of Domestic Animals. Nutrient Requirements of Dairy Cattle. No. 3. National Academy of Sciences, p. 76. Washington D.C.

Steel R.G.D., Torrif J.H., 1960. Principles and Procedures of Statistics, p. 481, McGrawHiLl, New York. 